Scientific journal

PHYSICAL AND MATHEMATICAL EDUCATION

Has been issued since 2013 .

Науковий журнал

ФІЗИКО-МАТЕМАТИЧНА ОСВІТА

Видається з 2013.
ISSN 2413-158X (online)
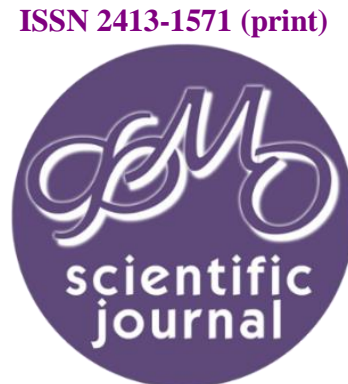

\title{
http://fmo-journal.fizmatsspu.sumy.ua/
}

Сердюкова Н.В. Взаємозв'язок між успішностю студентів у курсі загальної фізики і їх докурсовою підготовкою. Фізико-математична освіта. 2018. Випуск 3(17). С. 8-12.

Serdyukova N. The Relationship Between Students' Attainment In General Physics Course And Their Pre-Course Preparation. Physical and Mathematical Education. 2018. Issue 3(17). P. 8-12.

DOI 10.31110/2413-1571-2018-017-3-001

UDC 53:372.8

\section{THE RELATIONSHIP BETWEEN STUDENTS' ATTAINMENT IN GENERAL PHYSICS COURSE AND THEIR PRE-COURSE PREPARATION}

Abstract. This article presents a study of the students' achievement in the US university course of General Physics and their background, namely experience in studying physics in school (in US school physics is commonly a section within a general Physical Science course; time interval between previous and current courses; and taking prerequisite courses required for taking physics usually a few mathematics courses.

The study was performed at National University, San Diego, California, USA. A specifics of instruction at this university is a one-month course format, when students take a semester course within four weeks, which is achieved through concentration of class hours during this time period. A student can take only one course at a time. This format is convenient particularly for working adult students.

The difficulty of teaching physics in such course format is explained by a number of factors, among which uneven student preparation in physics, which may be connected to various time intervals between a previous and current courses which may lead to forgetting the material, some overestimation of their preparation to physics course by students, and insufficient quality of student learning outcomes in the prerequisite course to the physics course requirements.

The data presented in the article were obtained by surveying students and analyzing the results of two tests they take in the course: mid-term and final. We did a comparative investigation of two specializations, electrical engineers and biologists. This study demonstrated that students who had never taken physics earn 1.5-2 times more unsatisfactory grades than those who had taken it before. The course outcomes are also affected by the time interval between school graduation and the beginning of the physics course; especially significant is the interval of 10 years or more.

Based on the data obtained we made conclusions and developed practical recommendations for the instructors.

Key words. Physics, instruction, achievement, test, grade, time interval, preparation

\section{Introduction}

The US economy is currently in a time of major transition, as it moves from an agriculture and manufacturing to information economy. This new economy is firmly based on scientific knowledge and continuous innovation. The jobs of the future will require greater ability to invent, improve and adapt, and to see beyond present problems to future opportunities. It creates the need for a great number of scientifically educated and trained populace. Physics is the foundation of contemporary technologies, therefore high school physics is a prerequisite for nearly all STEM careers. However, high school students are reluctant to learn it - only $1 / 3$ of US high school students take physics; at the same time there is a significant shortage of qualified physics teachers - only $1 / 3$ of all high school physics teachers have a degree in physics education. [1]. This situation is leaving too many US students unprepared for college study in STEM disciplines.

Physics remains a difficult subject for undergraduate college students. Transition from high school to college is particularly painful for those students who choose majors that require physics as a general subject. Research demonstrates that students coming to the college and taking General Physics courses necessary for their majors in various areas have similar issues: students do not know the terminology, do not understand physics concepts, and cannot solve problems [2,3]. The issue definitely points to insufficient school Physics education. Still, when Physics is a mandatory subject in a number of college specializations, students have to master it. This situation calls for special approaches to teaching undergraduate Physics. The first step in improving undergraduate physics education is to understand the landscape in which the subject is being taught.

\section{State of College Physics Education}

A number of researchers critically assess current situation in physics college education. Sadler and Tai [4] report that students have problems understanding physics due to the low effectiveness of the pre-college preparation. They indicate, however, that high school teachers and college physics professors differ in their beliefs concerning the extent to which a high 
school physics course prepares students for college physics success. Yet their study demonstrates that taking a high school physical science course has a modestly positive relationship with the grade earned in introductory college physics. More rigorous preparation, including calculus and 2 years of high school physics, predicts higher grades. This finding is further exacerbated by Meltzer's research [5], which finds a positive correlation between students' mathematical skills and their exam grades in college physics. Meltzer found that students' normalized learning gains are not significantly correlated with their pretest scores on a physics concept test, but there is a substantial correlation between normalized learning gain and students' pre-instruction mathematics skill. These results suggest that students' initial level of physics concept knowledge might be largely unrelated to their ability to make learning gains in a physics course; however their pre-instruction algebra skills might be associated with their facility at acquiring physics conceptual knowledge. Aina's findings [6] further indicated that there was a significant difference in students' academic achievement in physics based on subject combination, and that academic achievement of students who combined physics with mathematics was better than those who combined with chemistry. These data are further confirmed by Kola [7].

Numerous studies bring about the conclusion that physics and mathematics are positively correlated in nature, that was why students' understanding in one assists in the other. School programs, nevertheless, do not adequately prepare candidates for colleges either in physics or in mathematics [2]. There is a deep gap between high school programs and entrance expectations of colleges. Among suggested recommendations was that subject-nature correlation is very important and must be seriously considered before student combine subjects of study in college. Another recommendation addresses the need to make secondary school and undergraduate college programs compatible and ensure smooth transition for those who want to continue their education.

\section{Study}

This study intended to find relationship between students' accomplishments in the course of college General Physics (GP) and their previous high school Physics and Mathematics education. Mathematics, incidentally, is commonly required as a socalled prerequisite course to be taken before GP. Another direction of study was the time period between a current Physics course student class and high school graduation. The time interval between school and college might be a significant factor in their mastering college physics because their knowledge might be diminishing with the time. The data obtained could be used to explain how these factors affect students' achievement in the college GP course, and suggest ways to improve their accomplishments. The study was conducted at National University.

Specifics of National University's (NU) unique approach to higher adult education is its accelerated $1 \times 1$ course model which compresses a semester-long course into a one-month format retaining the same amount of class hours. All one-month courses are taught sequentially, one after another, and taking two courses simultaneously is discouraged. This format is very attractive to working adult learners who need to obtain a degree in the field they already work sooner rather than later as adult learners are pressed for time. This model proved to be effective because it allows students to concentrate on one content, course structure and teaching style during this month and thus graduate sooner $([8,9]$. Practically all courses in the NU programs, both onsite and online, are offered in the $1 \times 1$ model format.

One of the difficulties in teaching college physics in general and in this accelerated course model in particular is students' uneven preparation for taking Physics course as quite a few students are not ready to take it, which makes teaching and learning in the same cohort a challenging task. This difficulty can be explained by several factors:

- Poor physics and math preparation in school.

- Erroneous expectations of the college physics course, which in students' mind is often likened to the school Physical Science course, that is actually not a Physics course but a combination of low-level Biology, Physics, Chemistry and Earth Sciences.

- Various time spans between school graduation and taking a university course.

- Insufficient prerequisite course mastery.

The hypothesis for this research was that if a student had taken physics courses in high school, successfully mastered prerequisite math college courses, and the shorter the time span between graduation from high school and taking a college course of GP was, the better outcomes they achieve in the college physics course.

This paper presents the results of the pilot study conducted in the 2015-16 academic year in two classes in different disciplines, one electrical engineering EE (22 students), and the other biology BI (16 students). The data were obtained through surveying students using a specially designed questionnaire which allowed to get and compare the information they supplied on whether they had taken physics and math at school, weather they had taken prerequisite math courses, and how long was the time span with the test results from midterm and final exams.

For quality indicators of the learning outcomes we used students' grades obtained in two exams, midterm and final. The grades students received were grouped, for convenience's sake, into three categories:

- $\operatorname{Good}(A, A-, B+, B)$

- Satisfactory (B-, C+, C, C-, D+)

- Unsatisfactory (D, D-, F)

- Time spans between school and university course were also set into three categories:

- 10 years and more

- More than 5 and less than10 years

- Less than 5 years

The midterm (MT) results deserve a special note: they are more demonstrative than the final test (FT) results, because the latter is more influenced by the instructor's and students' efforts in the class.

\section{Analysis}

The first step in this research was focused on finding correlation between students' taking physics at school and their MT grades. The results for MT for both classes are given in Table 1. The data allow to analyze students' grades and compare them to the fact whether they had taken physics at school $(\mathrm{Y})$ or not $(\mathrm{N})$. The data shown are in \%\%. 
Table 1.

Midterm results related to students' taking or not taking physics at school

\begin{tabular}{|c|c|c|c|c|c|}
\hline \multicolumn{6}{|c|}{ Electrical Engineers } \\
\hline \multicolumn{2}{|c|}{ Good } & \multicolumn{2}{|c|}{ Satisfactory } & \multicolumn{2}{|c|}{ Unsatisfactory } \\
\hline \multicolumn{2}{|c|}{18} & \multicolumn{2}{|c|}{41} & \multicolumn{2}{|c|}{41} \\
\hline $\mathrm{Y}$ & $\mathrm{N}$ & $\mathrm{Y}$ & $\mathrm{N}$ & $\mathrm{Y}$ & $\mathrm{N}$ \\
\hline 5 & 13 & 27 & 14 & 14 & 27 \\
\hline \multicolumn{6}{|c|}{ Biologists } \\
\hline \multicolumn{2}{|c|}{ Good } & \multicolumn{2}{|c|}{ Satisfactory } & \multicolumn{2}{|c|}{ Unsatisfactory } \\
\hline \multicolumn{2}{|c|}{19} & \multicolumn{2}{|c|}{25} & \multicolumn{2}{|c|}{56} \\
\hline $\mathrm{Y}$ & $\mathrm{N}$ & $Y$ & $\mathrm{~N}$ & $Y$ & $\mathrm{~N}$ \\
\hline 13 & 6 & 0 & 25 & 31 & 25 \\
\hline
\end{tabular}

As seen from Table1, the fact of taking physics in school affects the MT results to a certain extent: out of $41 \%$ of unsatisfactory grades among $\mathrm{EE}$, only $14 \%$ of the surveyed students had taken physics in school, while the remaining $27 \%$ had not, which evidently affected their test results. The majority of students who got satisfactory grades took physics in school $(27 \%$ vs. $14 \%$ ), however, there was an opposite relationship among students who got good grades (5\% vs. $13 \%$ ).

Among $\mathrm{BI}$, the number of students who received unsatisfactory grades is significantly higher and makes $56 \%$ (vs. $41 \%$ with EE). This can be explained by their initial professional predisposition, which does not explicitly require physics. Out of $56 \%$ of unsatisfactory grades among biologists, $31 \%$ had taken physics at school, and $25 \%$ had not, which makes us believe that physics at school was not taught and/or mastered well. Neither of students who got satisfactory grades took physics is school (25\%), but the majority of students who got good grades did (13\% vs. $6 \%$ ).

It is interesting, when we analyze the "good" and "satisfactory" grades, the results are different among these two specializations: among EE students only $5 \%$ had taken school physics, however $13 \%$ did not, but among $\mathrm{BI}$ the result is the opposite: $13 \%$ had taken physics in school, and $6 \%$ had not. We believe that engineers have a generally better preparation in Physics and Math due to their initial inclination for technology. BI students do not have that kind of an inclination, therefore school physics helped the good students. Interestingly, it did not play any role for the "satisfactory" biology students. In all, there has not been found a direct correlation between students MT grade and their previous physics education, which confirms Sadler and Tai's [4] and Maltzer's [5] conclusions mentioned earlier.

The second part of research looked into a possible correlation between students' achievement in math prerequisite courses and physics. Students were asked to assess their confidence level in math ( $\mathrm{H}$ - high, $\mathrm{L}-\mathrm{low})$ based on their prerequisite courses they had taken before physics classes.

Table 2.

Midterm results related to students' self-assessment of their math preparation

\begin{tabular}{|c|c|c|c|c|c|}
\hline \multicolumn{6}{|c|}{ Electrical Engineers } \\
\hline \multicolumn{2}{|c|}{ Good } & \multicolumn{2}{|c|}{ Satisfactory } & \multicolumn{2}{|c|}{ Unsatisfactory } \\
\hline \multicolumn{2}{|c|}{18} & \multicolumn{2}{|c|}{41} & \multicolumn{2}{|c|}{41} \\
\hline $\mathrm{H}$ & $\mathrm{L}$ & $\mathrm{H}$ & $\mathrm{L}$ & $\mathrm{H}$ & $\mathrm{L}$ \\
\hline 15 & 3 & 18 & 23 & 11 & 30 \\
\hline \multicolumn{6}{|c|}{ Biologists } \\
\hline \multicolumn{2}{|c|}{ Good } & \multicolumn{2}{|c|}{ Satisfactory } & \multicolumn{2}{|c|}{ Unsatisfactory } \\
\hline \multicolumn{2}{|c|}{19} & \multicolumn{2}{|c|}{25} & \multicolumn{2}{|c|}{56} \\
\hline $\mathrm{H}$ & $\mathrm{L}$ & $\mathrm{H}$ & $\mathrm{L}$ & $\mathrm{H}$ & $\mathrm{L}$ \\
\hline 12 & 7 & 12 & 13 & 16 & 40 \\
\hline
\end{tabular}

As seen from Table 2, there is an evident correlation between students' self-assessment of their math preparation and their MT results in all groups of "good", "satisfactory" and "unsatisfactory" students: the more confident they were in the math preparation, the higher grades in physics they earned, and vice versa: the less confident, the poorer grades. This finding confirms the conclusions presented in Sadler and Tai's (2001) and Maltzer's (2002) research.

The next part of the research was to analyze the relation between students' achievements (grades) and temporal interval for engineers and biologists between college course and school graduation (\%):

Table 3.

Students' achievements (grades) and time interval between school graduation and college course

\begin{tabular}{|l|c|c|c|c|c|c|}
\hline $\begin{array}{l}\text { Time } \\
\text { Interval }\end{array}$ & \multicolumn{2}{|c|}{ Electrical Engineers } & \multicolumn{3}{c|}{ Biologists } \\
\hline Grades & Good & Satisfactory & Unsatisfact. & Good & Satisfactory & Unsatisfact. \\
\hline$\leq 5 \mathrm{yrs}$ & 0 & 13 & 5 & 0 & 0 & 0 \\
\hline $5-10 \mathrm{yrs}$ & 5 & 5 & 0 & 0 & 0 & 6 \\
\hline$\geq 10 \mathrm{yrs}$ & 0 & 9 & 9 & 13 & 0 & 25 \\
\hline
\end{tabular}

As follows from Table 3, when the time interval between school and college physics exceeded 10 years, it had a significant effect on the MT grades which rose to $50 \%$ unsatisfactory grades among EE and $65.8 \%$ for BI students.

The number of biology students who got unsatisfactory grades having graduated from school 10 or more years before college class, is significantly higher than that of the EE students. 
The number of unsatisfactory grades for students who had an interval from 5 to 10 years is different and almost the same among groups of biologists and $\mathrm{EE}-6 \%$ and $5 \%$ accordingly.

For students who graduated from school less than 5 years ago, the outcomes look much better: 13\% EE students received satisfactory grades, and only $5 \%$ - unsatisfactory grades. Due to small number of BI students we cannot make definite conclusions, but we anticipate that the shorter the interval between school and college, the better students' knowledge and the higher the grade for college course.

The majority of students - 20 out of $22 \mathrm{EE}$ and 15 out of $16 \mathrm{BI}$ had taken prerequisite classes which were defined as mandatory for Physics courses within the previous 10 years. Typically it is College Algebra and trigonometry. These prerequisites are helpful for studying Physics.

Let's consider temporal interval for the prerequisites. We chose four intervals:

1. Less than one year

2. Between 1 and 5 years

3. Between 5 and 10 years

4. More than 10 years.

Students' achievements (grades) and time interval between prerequisite math course and physics course

\begin{tabular}{|c|c|c|c|c|c|c|}
\hline Time Interval & \multicolumn{3}{|c|}{ Electrical Engineers } & \multicolumn{3}{|c|}{ Biologists } \\
\hline Grades & Good & Satisfact. & Unsatisfac. & Good & Satisfac. & Unsatisfac. \\
\hline 1.Less than one year & 54 & 33 & 13 & 45 & 33 & 22 \\
\hline 2.Less than 5 yrs. & 40 & 60 & 0 & 0 & 67 & 33 \\
\hline 3.Between 5 and 10 yrs. & 0 & 0 & 0 & 0 & 0 & 0 \\
\hline 4. More than 10 yrs. & 50 & 50 & 0 & 100 & 0 & 0 \\
\hline
\end{tabular}

As follows from Table 4, the shorter time interval between prerequisite math course and physics course, the higher are the grades for MT in physics, except for a few students who had taken prerequisite courses 10 or more years ago. As for the biologists, the results obtained for the $4^{\text {th }}$ time interval are, in our opinion, an exception. It confirms the previous observation that the impact of prerequisite courses on students' achievement is significant.

The Final's results are higher than the Midterms ones: GPA for MT was 1.5, and for FT 2.32 (EE), and for BI 1.03 and 2.17. However, $14 \%$ of EE and $12.5 \%$ of BI earned unsatisfactory grades in the Finals. In both classes almost a half of students had taken Physics 10 or more years ago, and the other half had never taken it.

Teaching college physics can be improved using advanced methodologies, techniques and technologies. One of the ways to enhance quality of the learning is offered by application of the Instructional Iterative Model (ITT) developed by the author [10]. This model proved to be an effective instructional model helping improve student's understanding and retention of the new material by revisiting basic concepts and applications presented in the course a number of times in an increasingly more sophisticated context. Accelerated Physics classes taught on the basis of this model demonstrated a marked increase in productivity of learning and improvement of recall.

\section{Conclusion}

The results of this research demonstrated that,

- School preparation in Physics in the US schools is insufficient for further college study.

- This situation is exacerbated by an extended interval between school graduation and college admission.

- Previous preparation in math and physics positively affects students achievements in the college physics course, however math preparation impacts students' achievement in physics more than previously taken physics courses.

- Temporal interval between college physics course and students' previous study, both at school and in prerequisite courses, as expected, made a marked difference: the sooner students started college, the better their outcomes were.

\section{Recommendations}

1. To compensate for the evident gap in student preparation in physics, we suggest to introduce remediation courses for those who need it before taking college physics courses.

2. Another option is tutoring in physics offered to students outside the class, both in face-to-face and online formats.

3. The mandatory policy about prerequisite mathematics courses must be maintained.

4. Students need to be made aware that the shorter the interval between school graduation and prerequisite math courses and college physics course, the easier it is to learn physics and the better will be the outcomes.

5. Integrating advanced methodologies, techniques and technologies into college physics can help improve students' understanding, retention and problem solving skills.

1. The Crisis in Physics Education (2011). Physics Teacher Education Coalition. Cornell University. https://phystec.physics.cornell.edu/content/crisis-physics-education

2. Sheehy, K. (2012). High School Students Not Prepared for College, Career. U.S News and world Report. https://www.usnews.com/education/blogs/high-school-notes/2012/08/22/high-school-students-not-prepared-for-collegecareer

3. Adapting to a changing world: Challenges and Opportunities in Undergraduate Physics Education (2013). Report. National Academy of Sciences. 
4. Sadler, P., Tai, R. (2001). Success in Introductory College Physics: The Role of High School Preparation. Science Education, February 2001, 111-136.

5. Meltzer, D. (2002). The relationship between mathematics preparation and conceptual learning gains in physics: A possible "hidden variable" in diagnostic pretest score. Am. J. Phys. 70(12), December $2002.1259-1268$. http://people.physics.tamu.edu/toback/TeachingArticle/Meltzer_AJP.pdf

6. Aina, J.K. (2013). Subject Area Specialization-Combination Correlation in Colleges of Education: Effect on Students' Achievement in Physics. Open Journal of Education, Vol.1(3), 2013, pp. 113-116.

7. Kola, A. (2014). Subject Area Specialization-Combination Correlation in Colleges of Education: Effect on Students' Achievement in Physics. Researchgate. https://www.researchgate.net/ publication/263656603 Subject_Area_SpecializationCombination_Correlation_in_Colleges_of_Education_Effect_on_Students\%27_Achievement_in Physics

8. Csikszentmihalyi, M (1982). Toward a psychology of optimal experiences. Review of Personality and Social Psychology, No. 3: 13-36.

9. Serdyukov, P. (2008). Accelerated learning: What is it? Journal of Research in Innovative Teaching, 1(1), 2008, 36-59.

10. Serdyukova, N. (2008). Accelerated General Physics: Real Challenges and Possible solutions. Journal of Research in Innovative Teaching, 1(1), 2008, 95-112.

\section{ВЗАЕМОЗВ'ЯЗОК МІЖ УСПІШНОСТЮ СТУДЕНТІВ В КУРСІ ЗАГАЛЬНОЇ ФІЗИКИ І ЇХ ДОКУРСОВОЮ ПІДГОТОВКОЮ} Сердюкова Н.В.

Національний університет, Сан Дієго, США

Анотація. В даній статті досліджується взаємозв'язок між успішністю студентів в курсі загальної фізики американського університету та їх попереднім досвідом, а саме, досвідом вивчення фізики в школі (в середній школі США фрізика найчастіше вивчається в рамках загального курсу «Фізична наука»); часовим інтервалом між попереднім вивченням фізики в школі чи вузі і даними курсом; а також проходженням так званих обов'язкових попередніх (prerequisite) курсів, необхідних для запису на курс фізики - як правило, че кілька курсів математики.

Дослідження проводилося в Національному університеті (місто Сан Дієго, Каліфорнія, США). Особливість структури навчання в цьому університеті - це прискорений одномісячний формат курсів, коли за один місяць студент повинен освоїти семестровий обсяг матеріалу, що досягається концентрацією навчальних годин семестрового курсу протягом чотирьох тижнів. При цьому студент може обрати тільки один курс на місяць. Такий формат зручний перш за все для дорослих працюючих студентів.

Складність викладання фізики в таких курсах пов'язана з досить нерівномірною підготовкою студентів, що пояснюється різними проміжками часу між нинішнім курсом і попереднім вивченням фізики, що призводить до забування матеріалу, деякою переоцінкою студентами своєї підготовленості до курсу, і невідповідністю якості підготовки в обов'язкових попередніх курсах вимогам курсу фізики.

Представлені в статті дані були отримані шляхом анкетування студентів і аналізу результатів двох тестів (проміжного та фінального), які студенти виконували в рамках курсу фізики. Для порівняння ми провели дослідження в групах студентів двох спеціальностей: інженерів-електриків і біологів. Результати дослідження показали, що студенти, які не вивчали фізику в школі, незадовільні оцінки на тестах отримують в 1,5-2 рази частіше, ніж ті, хто вивчав фізику. На оцінках також позначається інтервал між закінченням школи і початком вивчення фізики в університеті; особливо показовий в цьому плані інтервал від 10 років і більше.

На підставі отриманих даних були зроблені висновки і розроблені практичні рекомендації для викладачів.

Ключові слова: фізика, викладання, успішність, тест, оцінка, часовий інтервал, підготовка. 